\title{
Determination of ceftiofur derivatives in serum, endometrial tissue, and lochia in puerperal dairy cows with fever or acute puerperal metritis after subcutaneous administration of ceftiofur crystalline free acid
}

\author{
X. von Krueger, ${ }^{*}$ P. Scherpenisse,† S. Roiger, $\ddagger$ and W. Heuwieser*1 \\ ${ }^{*}$ Clinic for Animal Reproduction, Faculty of Veterinary Medicine, Freie Universität Berlin; Königsweg 65, D-14163 Berlin, Germany \\ †Institute for Risk Assessment Sciences, Division Veterinary Public Health, Faculty of Veterinary Medicine, Utrecht University, \\ NL-3584 TD, Utrecht, the Netherlands \\ $\ddagger$ Bavarian Animal Health Service, Department of Food-Hygiene, D-85586 Poing, Germany
}

\begin{abstract}
Acute puerperal metritis (APM) is one of the most common diseases during the puerperal period. Systemic administration of ceftiofur for 5 consecutive days has been shown to be effective for treatment of APM. The objective of this study was to determine concentrations of ceftiofur derivatives in serum, endometrial tissue, and lochia of cows with fever postpartum or APM 4 to $6 \mathrm{~d}$ after treatment with a single subcutaneous dose of $6.6 \mathrm{mg}$ of ceftiofur crystalline free acid $(\mathrm{CCFA}) / \mathrm{kg}$ of estimated $\mathrm{BW}$ at the base of the ear. In the first experiment, samples from CCFA-treated cows with fever postpartum or APM $(\mathrm{n}=42)$ were taken on $\mathrm{d} 4,5$, or 6 after treatment. Concentrations of ceftiofur derivatives were quantified using an HPLC assay. Concentrations of active ceftiofur metabolite desfuroylceftiofuracetamide (DCA) were greatest at d 4 after treatment with CCFA in all samples, but they were considerably lower than the concentrations of DCA in healthy postpartum cows treated with the same dose of CCFA. The concentrations of DCA in serum, endometrial tissue, and lochia were affected by odor of vaginal discharge before treatment with CCFA. Mean concentrations of DCA could be detected above the reported minimal drug concentrations (minimum inhibitory concentrations, MIC) required to inhibit relevant pathogens such as Escherichia coli and Arcanobacterium pyogenes in serum on all days and in endometrial tissue and lochia only on d 4 in CCFA-treated cows with fetid vaginal discharge before treatment. In the second experiment, samples from CCFA-treated cows with APM $(\mathrm{n}=8)$ were taken on d 0 (before treatment) and d 4, 5, and 6 after treatment. Mean concentrations of DCA in serum and lochia were similar on d 4 to 6 in both laboratories. Furthermore, determined concentrations of DCA from both laboratories were correlated for serum and lochia.
\end{abstract}

Received August 6, 2012.

Accepted October 27, 2012.

${ }^{1}$ Corresponding author: w.heuwieser@fu-berlin.de
Mean concentrations of DCA could be detected above the reported MIC in serum and lochia only on d 4 . Our 2 experiments demonstrated that in postpartum cows with fever postpartum or APM concentrations above the MIC for relevant bacteria $(>0.5 \mu \mathrm{g} / \mathrm{mL}$ or $>0.5$ $\mu \mathrm{g} / \mathrm{g}$ ) of DCA could be sustained only for 4 (serum: 15/17; endometrial tissue: $2 / 17$; lochia: $1 / 16$ ) to $5 \mathrm{~d}$ (serum: 10/13; endometrial tissue: 1/13; lochia: 2/12) after a single treatment with CCFA only in a certain proportion of cows. Overall, our data provide first pharmacological evidence that a single subcutaneous administration of $6.6 \mathrm{~g}$ of CCFA $/ \mathrm{kg}$ of BW might not be sufficient to efficaciously treat APM in postpartum dairy cows.

Key words: acute puerperal metritis, ceftiofur, minimal inhibitory concentration, dairy cow

\section{INTRODUCTION}

Puerperal uterine infections are associated with decreased reproductive performance in dairy cows (Gilbert et al., 2005). Acute puerperal metritis (APM) is one of the most common diseases during the puerperal period (Galvão et al., 2009). Within $21 \mathrm{~d}$ postpartum APM is characterized by an abnormally enlarged uterus and a fetid watery red-brown uterine discharge, associated with signs of systemic illness (decreased milk yield, dullness, or other signs of toxemia) and fever $>39.5^{\circ} \mathrm{C}$ (Sheldon et al., 2006). Pyrexia is associated with the presence of specific uterine pathogens such as Escherichia coli and Arcanobacterium pyogenes, combined with certain anaerobic species such as Fusobacterium necrophorum and Prevotella melaninogenicus (Sheldon and Dobson, 2004). But fever is only an indicator for postpartum inflammation. Additional clinical signs such as uterine discharge are necessary to identify uterine bacterial infection (Sheldon et al., 2004b). A fetid mucus odor is associated with the bacterial growth densities for Trueperella pyogenes and E. coli (Williams et al., 2005). In previous studies, the definitions for 
puerperal metritis in early postpartum cows varied from mere fever (Zhou et al., 2001; Drillich et al., 2003; Drillich et al., 2007a) to fetid uterine discharge (Mateus et al., 2002; Melendez et al., 2004; Jeremejeva et al., 2010) or a combination of both signs (Drillich et al., 2001; Risco and Hernandez, 2003; Chenault et al., 2004; Drillich et al., 2007b; Galvão et al., 2009; Dubuc et al., 2011).

Ceftiofur (CEF) is a third-generation cephalosporin and highly effective against almost all gram-positive and gram-negative pathogens (Salmon et al., 1996). It is hydrolyzed to the active metabolite desfuroylceftiofuracetamide (DCA) in the liver. After a single CEF treatment in healthy postpartum cows (Okker et al., $2002)$ or CEF treatment ( $1 \mathrm{mg} / \mathrm{kg}$ of BW s.c.) for 3 consecutive days (Drillich et al., 2006a) in puerperal cows with retained fetal membranes (Drillich et al., 2006b), DCA could be detected in concentrations above the reported MIC required to inhibit relevant pathogens such as E. coli $(0.5 \mu \mathrm{g} / \mathrm{mL})$ and T. pyogenes $(0.125 \mu \mathrm{g} / \mathrm{mL})$. Systemic administration of CEF has been shown to be effective for treatment of APM (Drillich et al., 2001; Chenault et al., 2004). Ceftiofur also reduced the incidence of APM in cows with retained fetal membranes (Drillich et al., 2003; Drillich et al., 2006b). In the United States and Europe, CEF has been approved for the treatment of APM for 5 consecutive days. A survey on antibiotic usage conducted on 113 dairy farms identified failure to complete antimicrobial treatment course in $76 \%$ of the responding herds (Sawant et al., 2005). Anecdotal evidence from the practice suggests that, on average, only 2 to 3 treatments are administered for therapy of APM with the potential risk of suboptimal cure rates and reduced reproductive performance.

Ceftiofur crystalline free acid (CCFA; Naxcel; Pfizer Animal Health GmbH, Berlin, Germany), a sustainedrelease formulation of $\mathrm{CEF}$, has been approved for a single subcutaneous injection at the base of the ear with the indication of acute bovine interdigital necrobacillosis in the United States and Europe. Additionally, in Europe a single subcutaneous treatment of CCFA can be used for APM in cases where treatment with another antimicrobial has failed. As stated in the European label claim of CCFA, total plasma concentrations above $1.0 \mu \mathrm{g}$ of $\mathrm{DCA} / \mathrm{mL}$ should be maintained for at least $4 \mathrm{~d}$ after application. After a single administration of CCFA in healthy postpartum cows DCA concentrations exceeded the MIC for E. coli and T. pyogenes in serum, lochia, and endometrial tissue over a 7-d period (Witte et al., 2011). But no information is available about concentrations of DCA after a single subcutaneous treatment with CCFA in cows with APM. In the United States, CCFA is indicated for treatment of APM (0 to $10 \mathrm{~d}$ postpartum) associated with bacterial organisms susceptible of CEF in lactating dairy cattle in a 2-dose regimen $72 \mathrm{~h}$ apart. Therefore, the objective of this study was to determine concentrations of CEF derivatives in serum, endometrial tissue, and lochia of cows with APM 4 to $6 \mathrm{~d}$ after treatment with a single subcutaneous dose of $6.6 \mathrm{mg}$ of $\mathrm{CCFA} / \mathrm{kg}$ of estimated $\mathrm{BW}$ at the base of the ear.

\section{MATERIALS AND METHODS}

All procedures in this trial were conducted according to the International Cooperation on Harmonization of Technical Requirements for Registration of Veterinary Medicinal Products (VICH, Brussels, Belgium) regulations relating to Good Clinical Practice and Clinical Trials (GCP). The participating farmers and the local veterinarians were informed about all relevant characteristics of the study design (informed consent). The objective of a first experiment was to determine concentrations of DCA in serum, lochia, and endometrial tissue of lactating cows with APM after a single subcutaneous administration of CCFA 4 to $6 \mathrm{~d}$ after treatment. Because the results of this trial were unexpected a second experiment was conducted to corroborate findings by comparing the concentrations of DCA in serum and lochia of cows with APM after single subcutaneous treatment with CCFA in 2 independent laboratories.

\section{Experiment 1}

Study Animals. Experiment 1 was conducted on 2 commercial dairy farms in Brandenburg, Germany, owned by the same farmer. Herd sizes were 1,025 (herd A) and 1,162 (herd B) cows. Animals were housed in freestall facilities with cubicles, rubber mats, and slotted floors all year round. Cows were dried off $45 \mathrm{~d}$ before the expected date of calving. Four weeks before expected calving, cows were housed in a freestall barn with straw bedding and fed a TMR consisting of $49.1 \%$ grass silage, $43.9 \%$ corn silage, $6.5 \%$ barley straw, and 0.5 mineral mix $\left(\mathrm{NE}_{\mathrm{L}}=1.43 \mathrm{Mcal} / \mathrm{kg}\right)$, distributed 2 times per day. Lactating cows were fed a TMR consisting of $2.5 \%$ mineral mix, $35.2 \%$ grass silage, $32.2 \%$ corn silage, $20.1 \%$ pressed pulps, $3.8 \%$ rape seed, $3.8 \%$ soybean meal, and $2.5 \%$ sugar beet pulp $\left(\mathrm{NE}_{\mathrm{L}}=1.55\right.$ $\mathrm{Mcal} / \mathrm{kg}$ ), distributed 2 times per day after milking. Average milk yields were 9,200 kg per lactation $(4.2 \%$ fat and $3.3 \%$ protein) and 9,300 kg per lactation $(4.2 \%$ fat and $3.3 \%$ protein) in herd $\mathrm{A}$ and $\mathrm{B}$, respectively. Cows calving between May 2010 and December 2010 were included $(\mathrm{n}=42)$.

Study Design. Relevant data were recorded for each cow, including the calving process $(1=$ no assistance, 
$2=$ slight assistance, and $3=$ needed assistance), retention of fetal membranes, and number of calves. Concomitant treatments [e.g., fluid therapy and nonsteroidal antiinflammatory drugs (NSAID)] were given at the discretion of the attending veterinarian and recorded. For $6 \mathrm{~d}$ after enrollment, additional or escape antimicrobial treatment was only allowed if the cow's life was in danger. Cows with a caesarean section and cows that were not supposed to be bred after calving were not enrolled in the study.

Rectal temperature of all postpartum cows was measured daily between 0500 and $0800 \mathrm{~h}$ for $10 \mathrm{~d}$ after calving. Cows experiencing a rectal temperature of $\geq 39.5^{\circ} \mathrm{C}$ (Zhou et al., 2001) once during this period received treatment consisting of a single subcutaneous dose of $6.6 \mathrm{mg}$ of CCFA $/ \mathrm{kg}$ of estimated BW at the base of the ear. Additionally odor (fetid or nonfetid) and texture (watery or viscous) of vaginal discharge was recorded at the day of enrollment according to the definition of APM by Sheldon et al. (2006). After enrollment, rectal temperature was measured for 6 more days.

To determine the concentrations of DCA in serum, endometrial tissue and lochia of CCFA-treated cows with fever postpartum $(\mathrm{n}=29)$ or APM $(\mathrm{n}=13)$, samples of blood, endometrial tissue, and lochia were collected on d $4(\mathrm{n}=12), 5(\mathrm{n}=17)$, or $6(\mathrm{n}=13)$ after enrolment. A cow was considered clinically cured if an antimicrobial escape therapy had not been administered during $6 \mathrm{~d}$ after enrolment and rectal temperature was $<39.5^{\circ} \mathrm{C}$ at the end of the observation period.

\section{Experiment 2}

Study Animals. Experiment 2 was conducted on a commercial dairy farm in Brandenburg, Germany, with a herd size of 643 cows. Cows were dried off 45 $\mathrm{d}$ before the expected date of calving and housed in a tiestall barn with straw bedding. Cows from calving to 7 DIM belonged in this group. These cows received $64.7 \%$ grass silage, $32.8 \%$ corn silage, $1.7 \%$ hay, $0.3 \%$ corn, and $0.5 \%$ mineral mix $\left(\mathrm{NE}_{\mathrm{L}}=1.49 \mathrm{Mcal} / \mathrm{kg}\right)$ distributed 3 times per day. The average milk yield was $8,382 \mathrm{~kg}$ per lactation (4.27\% fat and $3.61 \%$ protein). Seventeen cows calving in July 2011 were included in this trail.

Study Design. The rectal temperature of postpartum cows was measured daily between 1000 and 1100 $\mathrm{h}$ for $5 \mathrm{~d}$ after calving. Cows experiencing a rectal temperature of $\geq 39.5^{\circ} \mathrm{C}$ (Zhou et al., 2001) once during this period were assigned to the treatment group $(\mathrm{n}=8)$ and received treatment consisting of a single subcutaneous dose of $6.6 \mathrm{mg}$ of CCFA $/ \mathrm{kg}$ of estimated BW at the base of the ear. Healthy cows experiencing a rectal temperature of $<39.5^{\circ} \mathrm{C}$ during this period remained untreated and served as controls $(\mathrm{n}=9)$. After enrollment, rectal temperature was measured for 7 more days. In the control group, blood and lochia samples for baseline concentrations were collected at 5 DIM. In the CCFA group, blood and lochia samples were taken for baseline before treatment on d 0 and additional samples after treatment on d 4, 5, and 6 .

\section{Methods of Sampling}

Blood samples were collected by coccygeal venipuncture using sterile vacuum tubes (Venoject II; Terumo Europe NV, Leuven, Belgium). Blood samples were centrifuged at 3,500 $\times g$ for $8 \mathrm{~min}$ at room temperature. Serum was divided into 2 aliquots, transferred into serum tubes, and stored at $-20^{\circ} \mathrm{C}$ until analysis.

Before collection of samples from the uterus, the vulva and perineum were cleaned with dry paper towels. Biopsy samples of experiment 1 were taken from the base of either horn with a Kevorkian biopsy forceps [Wirtschaftsgenossenschaft deutscher Tierärzte eG (WDT), Garbsen, Germany) as described by Witte et al. (2011). A sample of uterine tissue (approximately $0.15 \mathrm{~g}$ ) was collected under transrectal control. The collected tissue was stored in sterile plastic tube (Eppendorf AG, Hamburg, Germany) at $-20^{\circ} \mathrm{C}$ until further analysis.

Finally, 1 sterile-gloved hand was introduced through the vagina into the uterus lumen and at least $10 \mathrm{~mL}$ of lochia was collected into Rotilabo screw-cap cans (Carl Roth GmbH \& Co. KG, Karlsruhe, Germany). Two aliquots of $5 \mathrm{~mL}$ each were stored in sterile milk tubes (Sarstedt AG \& Co., Nürnberg, Germany) at $-20^{\circ} \mathrm{C}$ for further analysis. Additionally, from 1 healthy, nontreated cow, $100 \mathrm{~mL}$ of serum, $10 \mathrm{~g}$ of endometrial tissue, and $100 \mathrm{~mL}$ of lochia were collected within $4 \mathrm{~d}$ after calving as blank material for HPLC analysis.

\section{Analytical Methods}

In experiment 1, concentrations of CCFA (molecular weight $=523.56 \mathrm{~g} / \mathrm{mol}$ ) residues were quantified in serum, endometrial tissue, and lochia samples using an HPLC assay with small modifications as described by Drillich et al. (2006a) and Witte et al. (2010, 2011). In this method, residues of CCFA were converted into DCA (molecular weight $=486.54 \mathrm{~g} / \mathrm{mol}$ ), which was determined by liquid chromatography-mass spectrometry (LC-MS). The limit of quantification of the method was $0.1 \mu \mathrm{g}$ of $\mathrm{DCA} / \mathrm{mL}$ for serum and $0.1 \mu \mathrm{g}$ of $\mathrm{DCA} / \mathrm{g}$ in lochia and endometrial tissue.

In experiment 2 , all samples were sent to 2 independent laboratories for analysis of concentrations of CCFA in serum and lochia. The first laboratory was the same as 
in experiment 1 , conducting the same methods. In the second laboratory, residues of CCFA including metabolites were converted into DCA, which was determined by HPLC. In brief, $0.2 \mathrm{~mL}$ of serum or $0.5 \mathrm{~g}$ of lochia was mixed with $0.8 \mathrm{~mL}$ of water and $4.0 \mathrm{~mL}$ of sodium phosphate $(0.01 \mathrm{M})$ and sodium hydroxide solution $(0.1$ $N)$ at $\mathrm{pH} 8.2$ to 8.7 , adding $100 \mathrm{mg}$ of dithioerythritol, and incubated at $50^{\circ} \mathrm{C}$ for $15 \mathrm{~min}$. After elution of DCA from a Bond Elut C18-solid-phase extraction (SPE) cartridge (Agilent Technologies, Lake Forest, CA), the eluates were passed over a cation-exchange SCX SPE column (Agilent Technologies). The extract was then determined by HPLC. The limit of quantification of the method was $0.05 \mu \mathrm{g}$ of $\mathrm{CCFA} / \mathrm{mL}$ for serum and 0.02 $\mu \mathrm{g}$ of CCFA/g in lochia.

\section{Statistical Analyses}

Concentrations of DCA of $\geq 0.5 \mu \mathrm{g} / \mathrm{mL}$ or $\geq 0.5 \mu \mathrm{g} / \mathrm{g}$ and $\geq 0.125 \mu \mathrm{g} / \mathrm{mL}$ or $\geq 0.125 \mu \mathrm{g} / \mathrm{g}$ are relevant for the potential efficacy of a treatment against $E$. coli and T. pyogenes (Sheldon et al., 2004a). Therefore, these concentrations were regarded as threshold values, as described by Drillich et al. (2006a). All data were recorded on data capture forms and transferred into a spreadsheet (Excel 2010; Microsoft, Munich, Germany). Descriptive statistical analyses were carried out with PASW (version 18.0; SPSS Inc. Munich, Germany). Results are presented as means \pm standard error of the mean. Correlations between concentrations of DCA in serum, endometrial tissue, and lochia were tested using the Spearman rank correlation $\left(\mathbf{r}_{\mathbf{s}}\right)$ for nonparametric variables. A linear regression model was run to calculate if DCA concentrations in serum would be a predictor for DCA concentrations in endometrial tissue and lochia, including odor of vaginal discharge on the day of treatment and time after treatment as covariates. Univariate ANOVA was performed to determine effects of plausible factors [i.e., day of sampling (4 to 6), odor of lochia (fresh vs. fetid), and interactions between these factors].

Correlations between the 2 laboratories for concentrations of DCA in serum and lochia were tested using the Pearson correlation ( $\mathrm{r}$ ) for parametric variables. A clinical measurement comparison can be inappropriate using Pearson correlation. Therefore, the agreement between the different laboratories was graphically analyzed using the method of Bland and Altman (1986) with MedCalc (version 12.0.3.0.; MedCalc software bvba, Mariakerke, Belgium).

Correlation coefficients, adjusted correlation coefficients, confidence intervals, and $P$-values are reported. For Univariate ANOVA, confidence intervals were set at $95 \%$. For all statistical analyses, the level of significance was set at $\alpha=0.05$.

\section{RESULTS}

\section{Experiment 1}

The greatest DCA concentrations in serum, endometrial tissue, and lochia, respectively, were detected at d 4 after administration of CCFA (Table 1). Serum concentrations of DCA exceeded the reported MIC of $0.5 \mu \mathrm{g} / \mathrm{mL}$ for $E$. coli in most of the CCFA-treated cows. In few serum samples, concentrations of DCA were below $0.5 \mu \mathrm{g} / \mathrm{mL}$ at d $4(\mathrm{n}=1 / 12), 5(\mathrm{n}=2 / 17)$, and $6(\mathrm{n}=3 / 13)$ after administration of CCFA (Table 2 ). The concentrations of DCA in serum, however, were above the MIC for T. pyogenes, F. necrophorum, and Prevotella melaninogenica $(0.125 \mu \mathrm{g} / \mathrm{mL})$ for all CCFAtreated cows.

In endometrial tissue, mean concentrations of DCA were above the MIC for E. coli $(0.5 \mu \mathrm{g} / \mathrm{mL})$ and MIC for T. pyogenes, F. necrophorum, and P. melaninogenica $(0.125 \mu \mathrm{g} / \mathrm{mL})$ only on d 4 in CCFA-treated cows with fetid vaginal discharge before treatment $(\mathrm{n}=2 / 2$; Table 2). In most of the endometrial samples of CCFA-

Table 1. Concentration of desfuroylceftiofuracetamide (DCA; mean \pm SEM) in serum, endometrial tissue, and lochia on d 4, 5, and 6 after administration of a single dose of ceftiofur crystalline free acid (CCFA; $6.6 \mathrm{mg} / \mathrm{kg}$ of BW)

\begin{tabular}{|c|c|c|c|c|c|c|c|}
\hline $\begin{array}{l}\text { Days after } \\
\text { CCFA treatment }\end{array}$ & $\begin{array}{l}\text { Odor of vaginal } \\
\text { discharge at CCFA }\end{array}$ & \multicolumn{2}{|c|}{ Serum $(\mu \mathrm{g} / \mathrm{mL})$} & \multicolumn{2}{|c|}{ Endometrial tissue $(\mu \mathrm{g} / \mathrm{g})$} & \multicolumn{2}{|c|}{ Lochia $(\mu \mathrm{g} / \mathrm{g})$} \\
\hline \multirow[t]{4}{*}{4} & Fetid & 1 & $3.52^{1}$ & 1 & $0.99^{1}$ & 1 & $3.52^{1}$ \\
\hline & & 1 & $0.72^{1}$ & 1 & $1.31^{1}$ & 1 & $0.74^{1}$ \\
\hline & Fresh & 10 & $0.80 \pm 0.15$ & 9 & $0.27 \pm 0.09$ & 10 & $0.01 \pm 0.01$ \\
\hline & Total & 12 & $0.81 \pm 0.13$ & 11 & $0.43 \pm 0.13$ & 12 & $0.37 \pm 0.29$ \\
\hline 5 & Fetid & 5 & $0.68 \pm 0.13$ & 5 & $0.25 \pm 0.07$ & 5 & $0.40 \pm 0.31$ \\
\hline \multirow[t]{3}{*}{6} & Fetid & 6 & $0.69 \pm 0.11$ & 6 & $0.37 \pm 0.10$ & 6 & $0.83 \pm 0.47$ \\
\hline & Fresh & 7 & $0.56 \pm 0.05$ & 7 & $0.24 \pm 0.05$ & 6 & $0.04 \pm 0.02$ \\
\hline & Total & 13 & $0.62 \pm 0.06$ & 13 & $0.30 \pm 0.06$ & 12 & $0.43 \pm 0.26$ \\
\hline
\end{tabular}

${ }^{1}$ Data are presented for each cow individually; therefore, mean \pm SEM could not be calculated. 
Table 2. Number of samples (no./total no. of samples) with concentrations of desfuroylceftiofuracetamide (DCA) $<0.5$ and $<0.125 \mu \mathrm{g} / \mathrm{mL}$ (serum) or $<0.5$ and $<0.125 \mu \mathrm{g} / \mathrm{g}$ (endometrial tissue and lochia) after administration of a single dose of ceftiofur crystalline free acid (CCFA; $6.6 \mathrm{mg} / \mathrm{kg}$ of BW)

\begin{tabular}{|c|c|c|c|c|c|c|c|}
\hline \multirow[b]{2}{*}{$\begin{array}{l}\text { Days after } \\
\text { CCFA treatment }\end{array}$} & \multirow[b]{2}{*}{$\begin{array}{l}\text { Odor of vaginal } \\
\text { discharge at CCFA }\end{array}$} & \multicolumn{6}{|c|}{ Concentration of $\mathrm{DCA}^{1}$} \\
\hline & & $<0.5$ & $<0.125$ & $<0.5$ & $<0.125$ & $<0.5$ & $<0.125$ \\
\hline \multirow[t]{3}{*}{4} & Fetid & $0 / 2$ & $0 / 2$ & $0 / 2$ & $0 / 2$ & $0 / 2$ & $0 / 2$ \\
\hline & Fresh & $1 / 10$ & $0 / 10$ & $7 / 9$ & $3 / 9$ & $10 / 10$ & $10 / 10$ \\
\hline & Total & $1 / 12$ & $0 / 12$ & $7 / 11$ & $3 / 11$ & $10 / 12$ & $10 / 12$ \\
\hline 5 & Total & $2 / 17$ & $0 / 17$ & $15 / 17$ & $3 / 17$ & $15 / 16$ & $11 / 16$ \\
\hline \multirow[t]{3}{*}{6} & Fetid & $1 / 6$ & $0 / 6$ & $5 / 6$ & $1 / 6$ & $4 / 6$ & $3 / 6$ \\
\hline & Fresh & $2 / 7$ & $0 / 7$ & $7 / 7$ & $2 / 7$ & $6 / 6$ & $6 / 6$ \\
\hline & Total & $3 / 13$ & $0 / 13$ & $12 / 13$ & $3 / 13$ & $10 / 12$ & $9 / 12$ \\
\hline
\end{tabular}

${ }^{1}$ For serum, concentrations are in $\mu \mathrm{g} / \mathrm{mL}$; for endometrial tissue and lochia, concentrations are in $\mu \mathrm{g} / \mathrm{g}$.

${ }^{2}$ Minimum inhibitory concentration required to inhibit the growth of $90 \%$ of organisms $\left(\mathrm{MIC}_{90}\right)$ for Escherichia coli: <0.5 mg/mL; $\mathrm{MIC} 90$ for Arcanobacterium pyogenes, Fusobacterium necrophorum, and Prevotella melaninogenica: $<0.125 \mathrm{mg} / \mathrm{mL}$.

treated cows, concentrations of DCA were below 0.5 $\mu \mathrm{g} / \mathrm{mL}(\mathrm{d} 4: \mathrm{n}=7 / 11, \mathrm{~d} 5: \mathrm{n}=15 / 17, \mathrm{~d} 6: \mathrm{n}=12 / 13$; Table 2). The concentrations of DCA in endometrial tissue, however, were above the MIC for T. pyogenes, $F$. necrophorum, and P. melaninogenica $(0.125 \mu \mathrm{g} / \mathrm{mL})$ for CCFA-treated cows. In a few endometrial samples, concentrations of DCA were below $0.125 \mu \mathrm{g} / \mathrm{mL}$ at $\mathrm{d}$ $4(\mathrm{n}=3 / 11)$, d $5(3 / 17)$, and d $6(\mathrm{n}=3 / 13)$ after administration of CCFA (Table 2).

In lochia, mean concentrations of DCA were above the MIC for E. coli $(0.5 \mu \mathrm{g} / \mathrm{mL})$ and MIC for T. pyogenes, F. necrophorum, and P. melaninogenica ( 0.125 $\mu \mathrm{g} / \mathrm{mL}$ ) only on $\mathrm{d} 4$ in CCFA-treated cows with fetid vaginal discharge at the time of treatment $(\mathrm{d} 4: \mathrm{n}=$ $2 / 2$, d $5: \mathrm{n}=4 / 5$, d $6: \mathrm{n}=4 / 6$; Table 2 ). In most of the lochia samples of CCFA-treated cows, concentrations of DCA were in the categories $<0.5 \mu \mathrm{g} / \mathrm{mL}$ and $<0.125$ $\mu \mathrm{g} / \mathrm{mL}$ (Table 2).

The concentrations of DCA in serum, endometrial tissue, and lochia were affected by odor of vaginal discharge before treatment with CCFA. In serum, the day after treatment $(P=0.001)$ and the interaction between odor of vaginal discharge and day after treatment $(P=0.006)$ had an effect on the concentrations of DCA $\left(\mathrm{R}^{2}=0.36\right.$; adjusted $\left.\mathrm{R}^{2}=0.27\right)$. In lochia, the day after treatment $(P=0.024)$, odor of vaginal discharge $(P<0.001)$, and the interaction between odor of vaginal discharge and day after treatment $(P=0.012)$ had an effect on the concentrations of DCA $\left(\mathrm{R}^{2}=0.44\right.$; adjusted $\left.R^{2}=0.36\right)$. In endometrial tissue the odor of vaginal discharge $(P=0.007)$ and the interaction between odor of vaginal discharge before treatment and day after treatment $(P=0.033)$ also had an effect on the concentrations of DCA $\left(\mathrm{R}^{2}=0.29\right.$; adjusted $\mathrm{R}^{2}=$ $0.18)$.
Correlations between concentrations of DCA in serum and endometrial tissue was $\mathrm{r}_{\mathrm{s}}=0.489(P=0.001)$ and between concentrations of DCA in endometrial tissue and lochia was $\mathrm{r}_{\mathrm{s}}=0.604(P<0.001)$. The correlation between serum and lochia was lower $\left(\mathrm{r}_{\mathrm{s}}=0.300\right.$; $P=0.060)$. The concentration of DCA in serum was a predictor for concentrations of DCA in lochia $(P<$ 0.001 ) but not for concentrations of DCA in endometrial tissue $(P=0.087)$.

\section{Experiment 2}

The greatest DCA concentrations in serum and lochia were detected at $\mathrm{d} 4$ after administration of CCFA (Table 3). Mean concentrations of DCA in serum and lochia were similar on d 4 to 6 in both laboratories (Figure 1A and B). Furthermore, determined concentrations of DCA from both laboratories were correlated for serum $(\mathrm{r}=0.980 ; P<0.01)$ and lochia $(\mathrm{r}=0.944$; $P<0.01$ ). Serum concentrations of DCA exceeded the reported MIC of $0.5 \mu \mathrm{g} / \mathrm{mL}$ for E. coli only on d 4 after treatment with CCFA (Table 4). On d 5 after treatment, in 2 of 8 serum samples concentrations of DCA were below $0.5 \mu \mathrm{g} / \mathrm{mL}$, and on d 6 after treatment, in 5 of 8 (laboratory 1) and 4 of 8 (laboratory 2) serum samples concentrations of DCA were below $0.5 \mu \mathrm{g} / \mathrm{mL}$. The concentrations of DCA in serum, however, were above the MIC for $T$. pyogenes, F. necrophorum, and P. melaninogenica $(0.125 \mu \mathrm{g} / \mathrm{mL})$ for all CCFA-treated cows.

In lochia, DCA concentrations varied widely (Table $3)$. On d 5 and 6 after treatment with CCFA, in most lochia samples concentrations of DCA were below the reported MIC of $0.5 \mu \mathrm{g} / \mathrm{mL}$ for $E$. coli for both laboratories. For about half of the lochia samples the 
Table 3. Concentration of desfuroylceftiofuracetamide (DCA; mean \pm SEM) in serum and lochia samples of ceftiofur crystalline free acid (CCFA; $6.6 \mathrm{mg} / \mathrm{kg}$ of BW)-treated cows before (d 0) and after treatment (d 4 to 6) in 2 independent laboratories

\begin{tabular}{lccc}
\hline & & \multicolumn{2}{c}{ Concentration of DCA } \\
\cline { 3 - 4 } Matrix & Day & Laboratory 1 & Laboratory 2 \\
\hline Serum $(\mathrm{n}=8 ; \mu \mathrm{g} / \mathrm{mL})$ & 0 & $0.20 \pm 0.14$ & $0.15 \pm 0.11$ \\
& 4 & $1.03 \pm 0.11$ & $1.04 \pm 0.10$ \\
& 5 & $0.66 \pm 0.10$ & $0.68 \pm 0.10$ \\
Lochia $(\mathrm{n}=8 ; \mu \mathrm{g} / \mathrm{g})$ & 6 & $0.51 \pm 0.10$ & $0.48 \pm 0.06$ \\
& 0 & $0.11 \pm 0.11$ & $0.10 \pm 0.08$ \\
& 4 & $0.94 \pm 0.44$ & $1.08 \pm 0.46$ \\
& 5 & $0.11 \pm 0.06$ & $0.21 \pm 0.15$ \\
& 6 & $0.18 \pm 0.14$ & $0.26 \pm 0.15$ \\
\hline
\end{tabular}
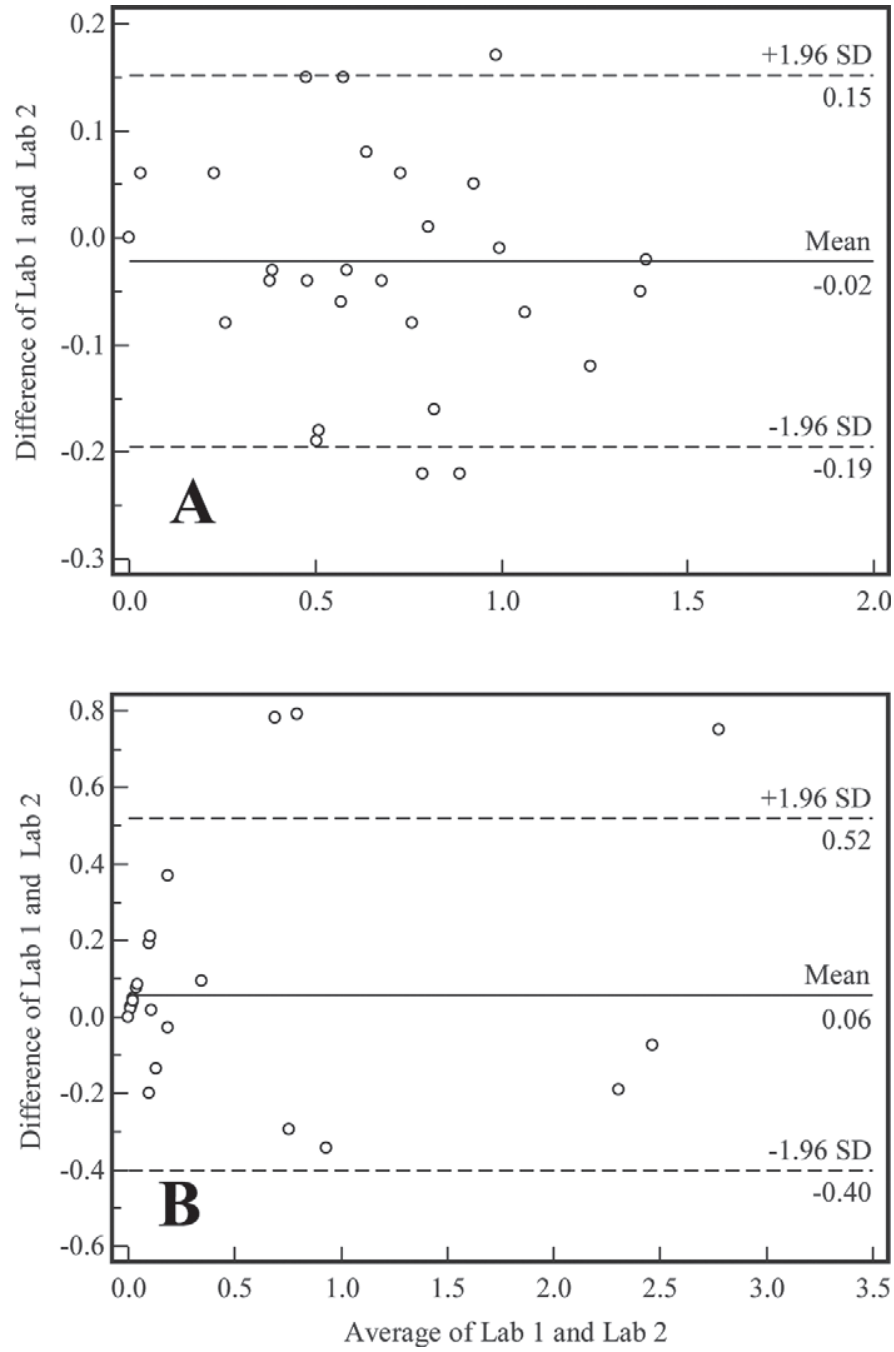

Figure 1. Bland-Altman plots comparing concentrations of desfuroylceftiofuracetamide (DCA) measured by 2 different laboratories in serum (A) and lochia (B) of cows treated with a single subcutaneous dose of $6.6 \mathrm{mg}$ of ceftiofur crystalline free acid $/ \mathrm{kg}$ of estimated BW at the base of the ear. concentrations of DCA were also below the MIC for $T$. pyogenes, $F$. necrophorum, and $P$. melaninogenica $(0.125 \mu \mathrm{g} / \mathrm{mL})$ for both laboratories (Table 4$)$.

\section{DISCUSSION}

The main objective was to determine concentrations of CEF derivatives in serum, endometrial tissue, and lochia of cows with fever postpartum or APM 4 to $6 \mathrm{~d}$ after treatment with a single subcutaneous dose of 6.6 $\mathrm{mg}$ of CCFA $/ \mathrm{kg}$ of estimated BW at the base of the ear. At present, no other published reports are available about concentration of DCA in serum, endometrial tissue, and lochia after single subcutaneous treatment with CCFA in cows with either fever postpartum or APM.

In the first experiment, concentrations of DCA were greatest at d 4 after treatment with CCFA in serum, endometrial tissue, and lochia, but they were considerably lower than the concentrations of DCA in healthy postpartum cows (serum: $1.54 \pm 0.68 \mu \mathrm{g} / \mathrm{mL}$; endometrial tissue: $1.19 \pm 0.47 \mu \mathrm{g} / \mathrm{g}$; lochia: $2.61 \pm 3.89$ $\mu \mathrm{g} / \mathrm{g}$ ) treated with the same dose of CCFA (Witte et al., 2011). As stated in the label claim of CCFA, total plasma concentrations above $1.0 \mu \mathrm{g} / \mathrm{mL}$ of DCA should be maintained for at least $4 \mathrm{~d}$ after application. But our results show mean concentrations of DCA considerably lower: $1.0 \mu \mathrm{g} / \mathrm{mL}$ on $\mathrm{d} 4$. On d 5 , the concentrations of DCA in CCFA-treated APM-diseased cows were also below the concentrations of DCA in similar samples taken from healthy postpartum cows (serum: $1.21 \pm$ $0.61 \mu \mathrm{g} / \mathrm{mL}$; endometrial tissue: $0.86 \pm 0.61 \mu \mathrm{g} / \mathrm{g}$; lochia: $0.96 \pm 1.15 \mu \mathrm{g} / \mathrm{g}$ ) treated with the same dose of CCFA in a previous study (Witte et al., 2011). On d 6 , as well, the concentrations of DCA in CCFA-treated APM-diseased cows were considerably lower than the concentrations of DCA in a previous study with healthy postpartum cows (serum: $0.82 \pm 0.42 \mu \mathrm{g} / \mathrm{mL}$; endometrial tissue: $0.70 \pm 0.68 \mu \mathrm{g} / \mathrm{g}$; lochia: $2.44 \pm 3.46 \mu \mathrm{g} / \mathrm{g})$ treated with the same dose of CCFA (Witte et al., 2011). Overall, these results contradict the hypothesis 
Table 4. Number of samples (no./total no. of samples) with concentrations of desfuroylceftiofuracetamide (DCA) $<0.5$ and $<0.125 \mu \mathrm{g} / \mathrm{mL}$ (serum) or $<0.5$ and $<0.125 \mu \mathrm{g} / \mathrm{g}$ (lochia) before (d 0 ) and after administration (d 4 to 6) of a single dose of ceftiofur crystalline free acid (CCFA; $6.6 \mathrm{mg} / \mathrm{kg}$ of BW) in 2 independent laboratories (Lab 1 and Lab 2)

\begin{tabular}{|c|c|c|c|c|}
\hline \multirow{3}{*}{$\begin{array}{l}\text { Days after } \\
\text { CCFA treatment }\end{array}$} & \multicolumn{4}{|c|}{ Concentration of $\mathrm{DCA}^{1}$} \\
\hline & \multicolumn{2}{|c|}{ Serum $^{2}$} & \multicolumn{2}{|c|}{ Lochia $^{2}$} \\
\hline & $<0.5$ & $<0.125$ & $<0.5$ & $<0.125$ \\
\hline \multicolumn{5}{|l|}{0} \\
\hline Lab 1 & $7 / 8$ & $6 / 8$ & $7 / 8$ & $7 / 8$ \\
\hline Lab 2 & $6 / 8$ & $6 / 8$ & $7 / 8$ & $6 / 8$ \\
\hline \multicolumn{5}{|l|}{4} \\
\hline Lab 1 & $0 / 8$ & $0 / 8$ & $5 / 8$ & $4 / 8$ \\
\hline Lab 2 & $0 / 8$ & $0 / 8$ & $5 / 8$ & $3 / 8$ \\
\hline \multicolumn{5}{|l|}{5} \\
\hline Lab 1 & $2 / 8$ & $0 / 8$ & $8 / 8$ & $5 / 8$ \\
\hline Lab 2 & $2 / 8$ & $0 / 8$ & $7 / 8$ & $6 / 8$ \\
\hline \multicolumn{5}{|l|}{6} \\
\hline Lab 1 & $5 / 8$ & $0 / 8$ & $7 / 8$ & $6 / 8$ \\
\hline Lab 2 & $4 / 8$ & $0 / 8$ & $6 / 8$ & $5 / 8$ \\
\hline
\end{tabular}

${ }^{1}$ For serum, concentrations are in micrograms per milliliter; for lochia, concentrations are in micrograms per gram.

${ }^{2}$ Minimum inhibitory concentration required to inhibit the growth of $90 \%$ of organisms $\left(\mathrm{MIC}_{90}\right)$ for Escherichia coli: $<0.5 \mathrm{mg} / \mathrm{mL} ; \mathrm{MIC}_{90}$ for Arcanobacterium pyogenes, Fusobacterium necrophorum, and Prevotella melaninogenica: $<0.125 \mathrm{mg} / \mathrm{mL}$.

that the concentration of DCA would be higher at the uterine level in cows with APM (Okker et al., 2002). The concentration of DCA in serum can be used to predict the concentration of DCA in lochia but not in endometrial tissue. Nevertheless, mean concentrations of DCA were higher in cows with fetid vaginal discharge before treatment in endometrial tissue and lochia at $\mathrm{d}$ 4 and 6 and in lochia at $\mathrm{d} 5$ than in cows with odorless vaginal discharge. Also, a significant effect of odor of vaginal discharge before CCFA treatment was found on mean concentrations of DCA in endometrial tissue $(P$ $=0.007)$ and lochia $(P<0.001)$.

In previous studies, the definitions for puerperal metritis in early postpartum cows varied from mere fever (Zhou et al., 2001; Drillich et al., 2003, 2007a) to fetid uterine discharge (Mateus et al., 2002; Melendez et al., 2004; Jeremejeva et al., 2010) or a combination of both signs (Drillich et al., 2001, 2007b; Risco and Hernandez, 2003; Chenault et al., 2004; Galvão et al., 2009; Dubuc et al., 2011). It can be assumed that in this study, cows with fever $\geq 39.5^{\circ} \mathrm{C}$ and fetid, watery, redbrown vaginal discharge had a case of APM (Sheldon et al., 2006). Cows with other diseases such as retained fetal membranes, mastitis, or lameness were excluded. Therefore, study animals with fever were considered to have a puerperal infection and included in the study group. It can be assumed that DCA accumulated in the inflamed endometrial tissue and lochia. This is in agreement with previous findings that the concentrations of DCA were higher at bacterially induced inflammatory sites of tissue chambers (Clarke et al., 1996).
However, we are aware that a gold standard for APM does not exist (Sheldon et al., 2006) and fever plus fetid discharge or fever alone might be imperfect criteria for diagnosing cows with bacterial infections of the uterus that require antibiotic treatment, even though those criteria a used in research and in the field.

Time above the MIC is the pharmacokinetic (PK) parameter most associated with efficacy of antibiotics. Serum concentrations above the MIC are important for an efficacious treatment of systemic infectious diseases associated with fever, such as APM. Serum concentrations of DCA exceeded the reported MIC of $0.5 \mu \mathrm{g} /$ $\mathrm{mL}$ for E. coli (Sheldon et al., 2004a) in most of the CCFA-treated cows. In single samples, however, concentrations of DCA decreased to $<0.5 \mu \mathrm{g} / \mathrm{mL}(1,1$, and 3 samples on d 4, 5, and 6, respectively; Table 2 ). Serum concentrations of DCA exceeded the reported MIC for T. pyogenes, F. necrophorum, and P. melaninogenica $(0.125 \mu \mathrm{g} / \mathrm{mL})$ for all CCFA-treated cows. These results are in agreement with a previous study treating healthy postpartum cows with CCFA (Witte et al., 2011).

In endometrial tissue, mean concentrations of DCA were above the MIC for E. coli and MIC for T. pyogenes, F. necrophorum, and $P$. melaninogenica only on d 4 in CCFA-treated cows with fetid vaginal discharge before treatment (Table 2). In most of the endometrial samples of CCFA-treated cows, concentrations of DCA were below $0.5 \mu \mathrm{g} / \mathrm{g}$ (Table 2). These results disagree with a previous study (Witte et al., 2011) that demonstrated mean concentrations of DCA in endometrial 
tissue of CCFA-treated healthy postpartum cows above the reported MIC of $0.5 \mu \mathrm{g} / \mathrm{g}$ for $E$. coli for most of the samples during the entire study period of $7 \mathrm{~d}$. The concentrations of DCA in endometrial tissue, however, were above the MIC for T. pyogenes, F. necrophorum, and P. melaninogenica $(0.125 \mu \mathrm{g} / \mathrm{g})$ for CCFA-treated cows. In a few endometrial samples, concentrations of DCA were below $0.125 \mu \mathrm{g} / \mathrm{mL}$ at $\mathrm{d} 4,5$, and 6 after administration of CCFA (Table 2).

For lochia, results were more heterogeneous. This observation is in agreement with previous studies (Okker et al., 2002; Drillich et al., 2006a; Witte et al., 2011). The levels of DCA found in lochia were mostly ineffective against bacteria in the uterine lumen. These results disagree with a previous study (Witte et al., 2011) that demonstrated mean concentrations of DCA in lochia of CCFA-treated healthy postpartum cows above the reported MIC for most of the cows until $6 \mathrm{~d}$ after treatment. If the study cows had fetid vaginal discharge before CCFA treatment, the mean concentrations of DCA in lochia on d 6 after treatment exceeded the MIC for E. coli and MIC for T. pyogenes, F. necrophorum, and P. melaninogenica $(0.125 \mu \mathrm{g} / \mathrm{g})$ in half of the samples. As it is known that true tissue concentrations, especially of water-soluble antibiotics, are underestimated due to dilution in extracellular fluid during the analytical process (Brown et al., 1995), in vivo and in vitro efficacy of antibiotics may differ.

The study design to start sampling not before d 4 was based on previous work that demonstrated DCA concentrations above the MIC for $7 \mathrm{~d}$ (Witte et al., 2011). Obviously, further research is necessary to study DCA concentrations in APM cows for the first $3 \mathrm{~d}$ after a single administration of CCFA.

Because the results of this first experiment were unexpected and contradicted the approved product information, a second experiment was conducted to corroborate findings by comparing the concentrations of DCA in serum and lochia of cows with APM after single subcutaneous treatment with CCFA in 2 independent laboratories. As the objective of this experiment was a comparison between laboratories, we refrained from collecting uterine biopsies. Concentrations of DCA were detected in serum and lochia of all treated cows in both laboratories. Mean concentrations of DCA in serum and lochia were similar on d 4 to 6 in both laboratories (Figure 1A and B). Furthermore, determined concentrations of DCA from both laboratories were correlated for serum $(\mathrm{r}=0.980 ; P<0.01)$ and lochia $(\mathrm{r}=0.944$; $P<0.01)$. The greatest DCA concentrations in serum and lochia were detected at $\mathrm{d} 4$ after administration of CCFA (Table 3). These results agree with the results of experiment 1 . The mean concentrations in serum and lochia on d 4 were higher than the mean concentrations of DCA in serum and lochia in experiment 1, but they were again lower than the results of a previous study with healthy postpartum cows treated with the same dose of CCFA (Witte et al., 2011).

Serum concentrations of DCA of both laboratories were above the reported MIC of $0.125 \mu \mathrm{g} / \mathrm{mL}$ for $T$. pyogenes, F. necrophorum, and P. melaninogenica for all CCFA-treated cows. This is in agreement with previous data from healthy postpartum cows treated with the same dose of CCFA (Witte et al., 2011). But serum concentrations of DCA exceeded the reported MIC of $0.5 \mu \mathrm{g} / \mathrm{mL}$ for $E$. coli only at d 4 for all CCFA-treated cows. At d 5 and 6 after treatment with CCFA, serum concentrations of DCA decreased to $<0.5 \mu \mathrm{g} / \mathrm{mL}$ in 2 of 8 and 4 (laboratory 1 ) and 5 of 8 (laboratory 2) cows, respectively (Table 4). Serum concentrations above the MIC of relevant pathogens are important for successful treatment of systemic infectious diseases associated with fever, such as APM. Our data demonstrate that effective serum concentrations of DCA can be sustained only for 4 to $5 \mathrm{~d}$ after a single administration of CCFA in postpartum cows with APM. This finding disagrees with previous studies about CCFA demonstrating sustained efficacious concentrations against bacteria causing acute bovine interdigital necrobacillosis over a 7.6-d period (Hibbard et al., 2004) and effective concentrations above the MIC for E. coli and T. pyogenes in serum of healthy postpartum cows over a 7 -d period (Witte et al., 2011).

The levels of DCA found in lochia were mostly ineffective against bacteria in the uterine lumen. Only about half of the lochia samples on d 4 showed concentrations of DCA above the MIC of $0.5 \mu \mathrm{g} / \mathrm{g}$ for $E$. coli and the MIC of $0.125 \mu \mathrm{g} / \mathrm{g}$ for $T$. pyogenes, F. necrophorum, and P. melaninogenica. On d 5 and 6, mean concentrations of DCA in lochia were mostly below the MIC and again differed from those of healthy cows treated with the same dose of CCFA (Witte et al., 2011). These results of our second experiment confirm those from experiment 1.

In a recent study, a total of 1,023 lactating postpartum dairy cows with APM were treated twice with CCFA (n $=514 ; 6.6 \mathrm{mg} / \mathrm{kg}$ of BW; Excede Sterile Suspension; Pfizer Animal Health, Kalamazoo, MI) or placebo (n = 509) $3 \mathrm{~d}$ apart (McLaughlin et al., 2012). The reason for this approach was the finding that concentrations of CEF derivatives in caruncle tissue fell below the MIC of E. coli $(0.5 \mu \mathrm{g} / \mathrm{g})$ by d 3 for cows treated with a single dose of CCFA (data on file; Study Report No. 1535R60-05-495; Pfizer Animal Health ). Therefore, those authors postulated that 2 doses of CCFA administered $72 \mathrm{~h}$ apart would effectively increase the clinical cure rate due to extended duration of levels of CEF above effective MIC levels for bacteria associated with metritis. 
Our 2 experiments demonstrated that in postpartum cows with APM, concentrations above the MIC for relevant bacteria $(>0.5 \mu \mathrm{g} / \mathrm{mL}$ or $>0.5 \mu \mathrm{g} / \mathrm{g})$ of DCA can be sustained only for 4 (serum: 15/17; endometrial tissue: $2 / 17$; lochia $1 / 16$ ) to 5 d (serum: 10/13; endometrial tissue: $1 / 13$; lochia $2 / 12$ ) after a single treatment with CCFA only in a certain proportion of cows. Overall, our data provides first pharmacological evidence that a single subcutaneous administration of $6.6 \mathrm{~g}$ of $\mathrm{CCFA} / \mathrm{kg}$ of $\mathrm{BW}$ might not be sufficient to efficaciously treat APM in postpartum dairy cows.

\section{ACKNOWLEGDMENTS}

We gratefully acknowledge the cooperation with the personnel of the study site. The work was exclusively funded by the Clinic of Animal Reproduction (Freie Universität Berlin, Berlin, Germany).

\section{REFERENCES}

Bland, J. M., and D. G. Altman. 1986. Statistical methods for assessing agreement between two methods of clinical measurement. Lancet 327:307-310.

Brown, S. A., N. R. Deleeuw, G. L. Stahl, and R. D. Roof. 1995 Characterization of plasma and lung concentration after ceftiofur sodium and tilmicosin phosphate administered subcutaneously to mice. J. Vet. Pharmacol. Ther. 18:385-387.

Chenault, J. R., J. F. McAllister, S. T. Chester Jr., K. J. Dame, F. M. Kausche, and E. J. Robb. 2004. Efficacy of ceftiofur hydrochloride sterile suspension administered parenterally for the treatment of acute postpartum metritis in dairy cows. J. Am. Vet. Med. Assoc. 224:1634-1639.

Clarke, C. R., S. A. Brown, R. N. Streeter, J. M. Clarke, P. J. Hamlow, J. K. Callahan, V. L. Hubbard, A. K. Speedy, and G. E. Burrows. 1996. Penetration of parenterally administered ceftiofur into sterile vs. Pasteurella haemolytica-infected tissue chambers in cattle. J. Vet. Pharmacol. Ther. 19:376-381.

Drillich, M., S. Arlt, S. Kersting, A. A. Bergwerff, P. Scherpenisse, and W. Heuwieser. 2006a. Ceftiofur derivatives in serum, uterine tissues, cotyledons, and lochia after fetal membrane retention. J. Dairy Sci. 89:3431-3438.

Drillich, M., O. Beetz, A. Pfützner, M. Sabin, H.-J. Sabin, P. Kutzer, H. Nattermann, and W. Heuwieser. 2001. Evaluation of a systemic antibiotic treatment of toxic puerperal metritis in dairy cows. J. Dairy Sci. 84:2010-2017.

Drillich, M., N. Klever, and W. Heuwieser. 2007a. Comparison of two management strategies for retained fetal membranes on small dairy farms in Germany. J. Dairy Sci. 90:4275-4281.

Drillich, M., M. Mahlstedt, U. Reichert, B. A. Tenhagen, and W. Heuwieser. 2006b. Strategies to improve the therapy of retained fetal membranes in dairy cows. J. Dairy Sci. 89:627-635.

Drillich, M., A. Pfützner, H. J. Sabin, M. Sabin, and W. Heuwieser. 2003. Comparison of two protocols for the treatment of retained fetal membranes in dairy cattle. Theriogenology 59:951-960.

Drillich, M., D. Voigt, D. Forderung, and W. Heuwieser. 2007b. Treatment of acute puerperal metritis with flunixin meglumine in addition to antibiotic treatment. J. Dairy Sci. 90:3758-3763.

Dubuc, J., T. F. Duffield, K. E. Leslie, J. S. Walton, and S. J. Leblanc. 2011. Randomized clinical trial of antibiotic and prostaglandin treatments for uterine health and reproductive performance in dairy cows. J. Dairy Sci. 94:1325-1338.

Galvão, K. N., L. F. Greco, J. M. Vilela, M. F. Sá Filho, and J. E. P. Santos. 2009. Effect of intrauterine infusion of ceftiofur on uterine health and fertility in dairy cows. J. Dairy Sci. 92:1532-1542.
Gilbert, R. O., S. T. Shin, C. L. Guard, H. N. Erb, and M. Frajblat. 2005. Prevalence of endometritis and its effects on reproductive performance of dairy cows. Theriogenology 64:1879-1888.

Hibbard, B., W. L. Bryson, S. L. Follis, E. J. Robb, J. K. Callahan, and K. J. Dame. 2004. Duration of therapy with EXCEDE or Micotil in a bovine respiratory disease challenge model. Technical Bulletin EXD04019. Pharmacia \& Upjohn, Pfizer Inc., Kalamazoo, MI.

Jeremejeva, J., T. Orro, M. Valdmann, and K. Kask. 2010. Bacteriological and cytological findings during the late puerperal period after two different treatments of retained placenta followed by acute puerperal metritis. Acta Vet. Scand. 52:41.

Mateus, L., L. Lopes da Costa, F. Bernardo, and J. R. Silva. 2002. Influence of puerperal uterine infection on uterine involution and postpartum ovarian activity in dairy cows. Reprod. Domest. Anim. 37:31-35.

McLaughlin, C. L., E. Stanisiewski, M. J. Lucas, C. P. Cornell, J. Watkins, L. Bryson, J. K. S. Tena, J. Hallberg, and J. R. Chenault. 2012. Evaluation of two doses of ceftiofur crystalline free acid sterile suspension for treatment of metritis in lactation dairy cows. J Dairy Sci. 95:4363-4371.

Melendez, P., J. McHale, J. Bartolome, L. F. Archbald, and G. A. Donovan. 2004. Uterine involution and fertility of Holstein cows subsequent to early postpartum $\mathrm{PGF}_{2 \alpha}$ treatment for acute puerperal metritis. J. Dairy Sci. 87:3238-3246.

Okker, H., E. J. Schmitt, P. L. Vos, P. Scherpenisse, A. A. Bergwerff, and F. H. Jonker. 2002. Pharmacokinetics of ceftiofur in plasma and uterine secretions and tissues after subcutaneous postpartum administration in lactating dairy cows. J. Vet. Pharmacol. Ther. 25:33-38.

Risco, C. A., and J. Hernandez. 2003. Comparison of ceftiofur hydrochloride and estradiol cypionate for metritis prevention and reproductive performance in dairy cows affected with retained fetal membranes. Theriogenology 60:47-58.

Salmon, S. A., J. L. Watts, and R. J. Yancey Jr.. 1996. In vitro activity of ceftiofur and its primary metabolite, desfuroylceftiofur, against organisms of veterinary importance. J. Vet. Diagn. Invest. 8:332-336.

Sawant, A. A., L. M. Sordillo, and B. M. Jayarao. 2005. A survey on antibiotic usage in dairy herds in Pennsylvania. J. Dairy Sci. 88:2991-2999

Sheldon, I. M., M. Bushnell, J. Montgomery, and A. N. Rycroft. 2004a. Minimum inhibitory concentrations of some antimicrobial drugs against bacteria causing uterine infections in cattle. Vet. Rec. 155:383-387.

Sheldon, I. M., and H. Dobson. 2004. Postpartum uterine health in cattle. Anim. Reprod. Sci. 82-83:295-306.

Sheldon, I. M., G. S. Lewis, S. LeBlanc, and R. O. Gilbert. 2006 Defining postpartum uterine disease in cattle. Theriogenology 65:1516-1530.

Sheldon, I. M., A. N. Rycroft, and C. Zhou. 2004b. Association between postpartum pyrexia and uterine bacterial infection in dairy cattle. Vet. Rec. 154:289-293.

Williams, E. J., D. P. Fischer, D. U. Pfeiffer, G. C. England, D. E. Noakes, H. Dobson, and I. M. Sheldon. 2005. Clinical evaluation of postpartum vaginal mucus reflects uterine bacterial infection and the immune response in cattle. Theriogenology 63:102-117.

Witte, T. S., A. A. Bergwerff, P. Scherpenisse, M. Drillich, and W. Heuwieser. 2010. Ceftiofur derivates in serum and endometrial tissue after intramuscular administration in healthy mares. Theriogenology 74:466-472.

Witte, T. S., M. Iwersen, T. Kaufmann, P. Scherpenisse, A. A. Bergwerff, and W. Heuwieser. 2011. Determination of ceftiofur derivatives in serum, endometrial tissue, and lochia in puerperal dairy cows after subcutaneous administration of ceftiofur crystalline free acid. J. Dairy Sci. 94:284-290.

Zhou, C., J. F. Boucher, K. J. Dame, M. Moreira, R. Graham, J. Nantel, S. Zuidhof, L. Arfi, R. Flores, G. Neubauer, and J. Olson. 2001. Multilocation trial of ceftiofur for treatment of postpartum cows with fever. J. Am. Vet. Med. Assoc. 219:805-808. 